\title{
Introducing Literature to an EFL Classroom: Teacher's Instructional Methods and Students' Attitudes toward the Study of Literature
}

\author{
Cevdet Yilmaz \\ Assistant Professor of English \\ Canakkale Onsekiz Mart University, Faculty of Education, Department of English, Turkey \\ Tel: 0532-636-0316 E-mail: cyilmaz@comu.edu.tr
}

Received: August 18, 2011

Accepted: September 19, 2011

Published: January 1, 2012

doi:10.5539/elt.v5n1p86

URL: http://dx.doi.org/10.5539/elt.v5n1p86

\begin{abstract}
This study reports on a teacher-researcher's introductions of literary works to undergraduates enrolled in literature course in the department of English during a thirteen-week experiment. The main focus in the study is on the investigation of the undergraduates' attitudes toward the study of literature in English, as well as factors affecting their opinions. In doing so, the study aims to explore one possibility of how the teaching of literature can be made more accessible to EFL students, incorporating students' literature preferences and attitudes along with the teacher's own goals and selection of literary texts. The survey instrument employed in this study was a 27 -item questionnaire administered to 105 undergraduates in the department of English. The results indicate that such a strategy for the teaching of literature which incorporates students' literature preferences into teacher's instructional practices will help students make considerable gains in both the literary and language competence.
\end{abstract}

Keywords: EFL students' attitudes toward literature, Literature teaching, Literary competence, Literacy

\section{Introduction}

The continuing debate on whether literature can be employed to enhance the efficiency of language programs is well-known and longstanding (Carter, 1988; Lazar, 1993; Cook, 1994; Short, 1996; Tucker, 2006). Notwithstanding all the controversies and different stances taken by linguists, literary critics and practitioners (McKay, 1982; Spack, 1985), the relevant literature abounds with the reasons why the incorporation of literature into the English Language classroom can be beneficial. In this context, Smith (1972, p. 275) takes issue with the separation of language from literature in practice because "no teacher of literature ignores linguistic problems and no language teacher really wants to leave his students speaking a sterile impoverished version of the language". As can be seen, both literature and language can serve as the complement to each other, which is conducive to the development of language skills. Broadly speaking, this is why the gap between literature and language should be bridged as opposed to the unfortunate attempts to separate them. In addition, researchers have argued that literature is beneficial in the language learning process as it offers valuable authentic material, stimulates personal development in readers and helps contribute to readers' cultural as well as language enrichment (Carter \& Long, 1991; Collie \& Slater, 1987). These advantages, they move on to assert, can be gained provided that teachers are capable of choosing the materials which students are likely to find the most appealing by means of activities that promote participation, reader response and a solid integration between language and literature. Additionally, Akyel and Yalçın remind us of (1990, p. 175) the practitioners', that is, teachers' view of Literature in principle and maintain that they use Literature in their teaching practices

a. to broaden students' horizons by giving them a knowledge of the classics of literature;

b. to improve students' general cultural awareness;

c. to stimulate students' creative and literary imagination and to develop their appreciation of literature;

d. to introduce students to masterpieces in British and American literature as an educative experience, and to add to students' knowledge of the world at large.

Connected with this trend are three models proposed by Carter and Long (1991, p. 2-3) in order to justify the underlying reasons for using Literature in ELT classroom as follows:

Cultural model: This model enables the learners to understand and appreciate the different cultures and ideologies 
portrayed in the literary texts together with the developing of one's perception of humanity in the world.

Language model: This model emphasises the subtle and varied creative uses of the language coupled with the range of the literary texts. This can, in turn, help the learners to explore the relations between linguistic forms and literary meanings.

Personal growth model: This model enables students to achieve an engagement with the reading of literary texts by understanding our society, culture and ourselves, the relationships with people and institutions. It is also noted that the appreciation and evaluation of the complex cultural artefacts contribute to the personal growth of the learners.

In building on the reasons for the teaching of literature in a second language, Lazar (1993, p. 14-15) does not put forward any general categories like Carter and Long but asserts that literature should be used with students because:

- it is very motivating

- it is authentic material

- it has general educational value

- it helps students to understand another culture

- it is a stimulus for language acquisition

- it develops students' interpretative abilities

- it expands students' language awareness

- it encourages students to talk about their opinions and feelings

Last, according to Parkinson and Reid Thomas (2000, p. 9-11), literature serves as a good model for good writing; it is memorable, non-trivial and challenging, and it also helps assimilate the rhythms of a language; therefore facilitating intelligence and sensibility training (Banegas 2010, p. 2). These characteristics of literature lead us to suggest that the merits of literature are by no means confined to developing only writing skill as well as to adopting a traditional approach to language teaching. It is further claimed that literature helps improve form and discourse processing skills together with vocabulary expansion and reading skills. Furthermore, as Hall $(2005$, p. $47-57)$ puts, literature has experienced a revival with the advent of communicative approach in language teaching as it provides learners with authentic, pleasurable and cultural material.

The considerations outlined above could also be used to justify the incorporation of literary texts as novel, short story, poetry and play in a syllabus or course plan in the process of language teaching. These different types of literary texts, in turn, can serve as rich resources which provide stimulating language activities. To illustrate this, for instance, the act of reading a novel, as one type of literary text, enhances meaning making processes and language capacity in our learners (Widdowson 1984, p. 246). In respect of further advantages of using literary texts for language activities, Duff and Maley (1990) add that they offer a wide range of styles and registers; they are open to multiple interpretations and hence provide excellent opportunities for classroom discussion; and they focus on genuinely interesting and motivating topics to explore in the classroom.

However, practitioners particularly should be aware of the potential drawbacks when engaging in the literary texts in the classroom as the majority of students might come up with differing tastes of literature. The diversity of the literature classroom can in turn inhibit the pace of teaching and learning on the part of both students and teachers. Thus, it is important to note that these students should be introduced to the wide range of literary texts suited to their individual needs and interests. Yet, the concerns as to what type of literary texts should be given prominence and then how they are, in practice, treated in classroom are not given due attention. In this context, the former relates to the selection process of literary text, which is a crucial issue in maximizing the benefits of literature in language classroom. Generally, students and the text itself involve the two aspects of the criteria for selection. The literary texts selected should appeal to students' tastes, interests and hobbies, and should take into account their linguistic proficiency, cultural background, and literary background (e. g. Brumfit, 1981; Collie \& Slater, 1987; Lazar, 1993). At the same time, the considerations including length, genres, themes, classic status and the availability of the printed text are of great value in selecting appropriate literary texts for students (Carter \& Long, 1991; Mckay, 1982; Brumfit, 1981). Regarding the latter, the application of reader-response theory which stresses the synthesis between reader and text is having a growing influence on EFL literature theory in ELT classes (Carlisle, 2000). Reader-response theory points to the creative role of the reader in the process of interacting with the literary text. According to its proponents (Oster, 1989; Elliot, 1990; Hirvela, 1996), the literary and aesthetic experience of reading a novel or poem is the product of a dialogue between reader and text. To this end, the investigation into the teachers' practices in the literature class and students' perceptions of the study of literature can throw some light on 
the practical application of literary texts in conjunction with some literary theories as the present article would reveal.

\section{Literature Review}

While a large body of research on students' attitude towards general foreign language study has developed over the past two decades, few studies have focussed on students' attitude toward literature. As earlier studies have shown, eliciting information on students having different perceptions of literature does shed some light on our conception of students' attitudes toward literature. To illustrate, in their study, Davis, Gorell, Kline and Hsieh (1992, p. 320) examined undergraduates' attitudes toward the study of literature in a foreign language as well as factors affecting their opinions. The participants in the study were enrolled in introduction to literature courses in departments of French and Spanish. As the participants' responses to a questionnaire revealed, more than two-thirds of the respondents indicated positive attitudes toward foreign language study. In addition, two factors statistically treated as independent variables in the questionnaire, namely, the amount of leisure reading done in the foreign language, and the preferred learning styles, were found to be significantly related to students' attitudes towards literature study. In other words, both teachers' instructional methods and students' own reading habits have a considerable influence on students' motivation to study literature.

Given the wide scope of literature containing different literary genres such as novel, short story, poetry and drama, selecting appropriate literary texts appealing to students' tastes and needs is of particular interest. It is at this point that students' perception of literature becomes a valuable resource as this, in effect, leads us to highlight the relationship between the type of literary text and linguistic and literary competence. To give an example, Akyel and Yalçın (1990) investigated EFL high students' perceptions of prose fiction (i.e. novel and short story), poetry and drama together with their resulting contributions in developing language competence and literary competence. They concluded that the students viewed 'novel' as "the most effective literary form for helping them develop their linguistic skills and cultural awareness", and 'drama' "as the most effective in helping students improve oral expression and gain self-confidence in using English” (Akyel and Yalçı1990, p. 175). In contrast, 'poetry' and 'short stories' were thought to make the least contribution to students' language skills development.

Apart from these studies surveying the students' reactions to the literary genres, elaborating the aspects of literature which give the students trouble is relatively important. With this in mind, Hirvela and Boyle (1988) examined ESL working adult learners' attitudes towards literature courses offered in a degree program in a university. The purpose of the study was to identify which literary genres were most favoured or feared by the students and which aspects of literature were reported as being the most problematic by the students. Results of their study revealed that the students enjoyed 'prose fiction' most and feared 'poetry' most; moreover, the students viewed 'interpretation of theme' most difficult when engaging in literature, followed by language-related aspects of literature (e.g. unusual syntactic patterns and multiple meanings of a word). These results can provide insights into assisting teachers in focussing attention on the selection of the most suitable literary texts with students' preferences and perceived difficulty of literature in mind.

The above surveys do shed some light on our knowledge of how students feel about studying English literature thereby providing valuable implications for contextualizing the factors surrounding the integration of literature into ELT classroom. Nevertheless, there is still a need to investigate EFL learners' perceptions or attitudes towards studying literature. For one thing, the educational settings and students' literary tastes as well as their individual pace of learning can to a large extent vary. Furthermore, one can argue that the earlier surveys into the use of literature in language courses have no practical relevance in that the focus is mainly on eliciting information on students' perceptions of literature teaching. Research is also required to be able to explore a strategy for the teaching of literature which incorporates students' attitudes along with the more established factors of the teacher's classroom practice and selection of texts.

This study aimed to investigate undergraduates' attitudes towards the study of literature and explore a range of factors likely to affect their opinions along with the teacher's practical methods relating to literature instruction in ELT class. Moreover, the survey seeks to elicit students' reflections on literature instruction given by the teacher in 2009 academic year at Çanakkale Onsekiz Mart University, Turkey. Thus, the present investigation addressed the following research questions:

1. What are EFL students' favourable attitudes toward FL literary study?

2. What are EFL students' perceptions of the literature instruction?

3. Which independent variables are related to these students' attitudes towards the study of literature (Davis, Gorell, Kline and Hsieh,1992). 


\section{Method}

\subsection{Participants}

105 Turkish university students ( 75 females and 32 males) who enrolled in the author's EFL literature and language teaching class participated in the study. They were third-year students, aged 18 to 19, majoring in English language teaching studies. Most students had studied English for 12 years and had graduated from high school where they were exposed to intensive English courses in order to prepare for the Departments of English at Turkish Universities. As part of the curriculum imposed by Department of English, literature and language teaching course was the required course with three-hour credit a week. The course was taught two semesters successively. This particular class was chosen as the participants due to the following reasons. First, as the students taking this course acted as the participants in the study at the same time, inviting them to participate in this study, which was conducted alongside the teaching process by the author, would not affect their regular English course program. Second, students in the literature and language course generally had a higher English proficiency than their peers in the other classes as the study of literature was challenging in that students were assumed to have already acquired the basic linguistic and literary skills. Third, given that students had already encountered some basic literature in their second year, they were familiar with the types of literary texts together with the eminent writers from both British and American literature. Thus, it was felt that students' background knowledge on literature would enable us to provide firm evidence on the issues surrounding literature instruction in ELT classroom.

\subsection{Teaching Materials}

Nineteen literary works were chosen and employed in this study. The literary texts were selected on the premise that the majority of the students would tend to engage in the type of works that draw on universal themes and could arouse students' curiosity and also foster their love of reading. The materials included two novels, six short stories, six poems, and five plays (see Appendix A). The poems and short stories were introduced in their original version, whereas due to the time constraints, the novels and plays were presented through synopsis or plot summaries drawn from the literature resources on the Internet. The texts involved were made available to the students as handouts prior to every literature presentation by the teacher.

\subsection{Teaching Procedure}

The experiment lasted for thirteen weeks in the spring semester of 2010. The literature presentations were made in a three-period course (135 minutes) once a week, and a total of nineteen literary texts were introduced in the order of novels, short stories, poems, and plays taking into account students' general literary tastes which were in line with their literature background relating to the previous two-semester literature course. The course consisted of five components:

1. At the very beginning of the course, it was noted that the course would attempt to achieve an effective integration of literature to EFL classroom. Thus, both linguistic skills and literary skills were emphasised. Students did the assigned reading before coming to class. The course began with a brief introduction of the appealing as well as challenging novel (Lord of Flies).

2. Before setting out to analyse the literary works involved, the author and some background information on the literary text were briefly introduced to students. Some questions regarding the theme, plot and characterization of the literary text were raised for students to discuss, which in turn enhances students' understanding of the text.

3. The majority of class time was spent introducing a range of literary activities (e.g. star diagram, using the title and cover design, and getting in the mood, etc.) adopted from Collie and Slater (1987) which proved to be beneficial in teaching English. The students were given explicit instruction on these activities accompanied by the extracts from the original literary texts. Students were set relevant sections from the literary texts to experience their practical relevance to teaching literature in EFL classroom.

4. Class time also included the micro teaching in which students performed the selected activities designed for specific literary texts. All the activities were held in the classroom setting where each student became active participants in performing the literary tasks.

5. As a follow-up activity, students were asked to reflect on their parts involving micro teaching with a view to demonstrating the likely outcomes when integrating literary texts into the development of different language skills.

\subsection{Instrument}

The instrument used to investigate students' perceptions of literature was a twenty-seven-item questionnaire (see Appendix B) which was a modified version of the literature questionnaire developed by Davis, Gorell, Kline and Hsieh (1992). The items 12 and 27 on the questionnaire were also devised by the writer in order to determine the 
outcomes of the teaching practices in the literature class on the part of the students. 16 items in the questionnaire were designed for a Likert scale response, ranging from 1 (strongly agree) to 5 (strongly disagree), 2 items from 1 (often) to 5 (never), 1 item from 1 (extremely useful) to 5 (not useful at all), and 7 items from 1 (excellent) to 5 (poor). As for the remaining 1 item, the item 27 was made up of four options to choose. The internal reliability (Cronbach's alpha) of the scale was .84.

Following the presentation of all the 19 literary texts, the last literature class was devoted to administering the literature questionnaire thereby asking students to express their attitudes to the literary works introduced in the experiment. It took students about 30 minutes to finish the questionnaire.

The data were analyzed using the Statistical Package for the Social Sciences (SPSS) version 11.for Windows. The descriptive statistics were used to summarize, while the multiple regression analysis was used to compare the variables. For one thing, the use of multiple regression analysis was statistically significant in that it allowed us to investigate the overall impact of many independent variables on any dependent variable. For this purpose, we treated the second and third items on the questionnaire as dependent variables and the remaining twenty five as independent variables likely to predict these two dependent variables (see Table 4).

\section{Results}

\subsection{Results of Research Question One: What are EFL students' favourable attitudes toward FL literary study?}

In order to answer the first research question, concerning the undergraduate favourable attitudes towards the study of literature, the frequency and percentage of students' responses to the second and third items on the questionnaire (see Table 1) were calculated. As the results showed, there is an agreement among the students that such study is "personally rewarding" and that language departments should encourage their majors to take literature courses. When asked how much they agreed with the statement, "I find studying literature in English personally rewarding," $37.1 \%$ of the respondents indicated strongest agreement, while $38.1 \%$ marked the next strongest category. Of the remaining $24.8 \%, 16.2 \%$ marked three, $7.6 \%$ marked four, and only one student indicated strong disagreement with five. Among the respondents asked to rate degree of agreement or disagreement with the statement, "Pre-service teachers in the Department of English should be encouraged to take literature courses," $40 \%$ indicated strong agreement or one, while $35.2 \%$ marked the next strongest category, two. The remaining $24.8 \%$ of the students responded in the following way: $15.2 \%$ marked three; $6.7 \%$ marked four; $2.9 \%$ indicated strongest disagreement, or five. Apparently, these results point to the fact that the overwhelming majority of the respondents indicated positive attitudes (marking one or two) toward FL literary study.

\subsection{Results of Research Question Two: What are EFL students' perceptions of the literature instruction?}

The first item in this part sought to find out whether literary activities introduced in the course would serve as applicable teaching aids for the future English teaching of pre-service teachers. As cited above, a large number of the students with $84.8 \%$ agreed that the literary activities taught would benefit them, while almost $7 \%$ were dissatisfied with the literary gains. The four successive questions 15 to 18 on the questionnaire, as displayed in Table 2 , asked the participants to mark what literary genres they liked most in the presentations. The descriptive statistics of students' responses to the four literary genres were shown in Table 2. The data demonstrated that the overwhelming majority of the respondents liked short stories $(86.6 \%)$ most, followed by novels (79\%), plays $(66.2 \%)$, and finally poems $(62.9 \%)$. These responses make it evident that students appear to appreciate the prose represented by novel and short story, which lends itself well to their literary studies.

Item 13: How valuable have you found the approaches to teaching literature?

With the item 13 on the questionnaire, students were asked to rate the approaches to teaching literature (small group work, lecture, whole-class discussion and student-led) introduced by the instructor in the literature class. $87.6 \%$ of the students reported 'small group work' to be the most useful approach to treating the literary texts in the classroom setting. In addition, $70 \%$ of the respondents were convinced that 'whole-class discussion' and 'student-led' were virtually useful in studying literature. Contrary to the common assumptions, 'lecture' was considered as the least useful method by students with $49.5 \%$.

\section{Item 27: What language skill(s) does studying literature help improve?}

Given the language gains in literature class, $93.4 \%$ of the respondents perceived most improvement in reading comprehension. Moreover, $68.2 \%$ of the students perceived literature as making contribution to their writing skills. Relatively less improvement was indicated in speaking and listening abilities (almost $57.8 \%$ and $20 \%$ respectively). Only 19 students out of 105 noted that their listening abilities also seemed to improve as a result of their exposure to literature. 


\subsection{Results of Research Question Three: Which independent variables are related to these students' attitudes toward the study of literature?}

\section{A. Dependent Variable 1: I find Studying Literature in English Personally Rewarding}

The results of the multiple regression analysis of the first dependent variable "I find studying literature in English personally rewarding" pointed to the meaningful relationship between students' attitudes towards literature and the independent variables concerned ( $\mathrm{R}$ Square $=.704$ and $\mathrm{p}=.000$ ). As can be seen, three independent variables significantly related to attitudes toward FL literary study. The fist single independent variable, finding literature in NL rewarding, was significant $(p=000)$. That is, the more respondents did reading in NL, the more favourable their attitude was toward the study of FL literature. Six items related to preferred learning style, calculated together, constituted the second independent variable $(\mathrm{p}=.000)$. Respondents appeared to appreciate literary study provided that they were given opportunities to: 1) express their personal opinions in both FL and NL; 2) look for the underlying meaning of the text in both FL and NL; and 3) read about people and experiences both different from their own and unlike their own. Another single independent variable, "I can use the literary activities introduced in the course for my future English teaching" was also found to be significant $(p=.014)$. The more strongly students agreed that they could make the abundant use of the literary activities taught in the literature class, the more strongly they agreed that they found studying literature in English personally rewarding. A fourth independent variable, self-rating of FL reading ability was negatively correlated to this dependent variable $(p=.953)$. According to this finding, the lower students rated their reading ability in the FL, the more strongly they agreed that they enjoyed FL literature.

\section{B. Dependent Variable 2: Pre-service teachers in the Department of English should be encouraged to take literature course}

As was displayed in Table 4, data obtained from students' answers pertinent to the second dependent variable "Pre-service teachers in the Department of English should be encouraged to take literature course" emphasized the meaningful relationship between students' attitudes towards literature and the independent variables concerned ( $R$ Square $=.563$ and $\mathrm{p}=.000$ ). It follows that three independent variables were found to be positively correlated to this dependent variable. Notably, as was the case with the first dependent variable, finding literature in NL rewarding and preferred learning styles being the two independent variables related to the positive attitudes toward FL literary study ( $p=.000$ and $p=.000$, respectively). That is, the stronger the agreement that finding literature in NL was rewarding, the stronger the agreement that literature courses should be taken by FL majors.

Regarding the third significant independent variable, students' self-rating of their knowledge of the reading ability, as distinct from that of the dependent variable 1 , was found to be positively correlated to this dependent variable ( $p$ $=.031)$. That is, the higher students rated their knowledge of the reading ability, the more positive were their attitudes toward recommending FL literature courses for majors. As such, a fourth independent variable, using the literary activities for future teaching, was found to be negatively correlated to this dependent variable and was approaching significance $(p=.081)$. In terms of this finding, the more strongly students disagreed that they could make use of the literary activities in their future teaching, the more strongly they agreed that they should take literature courses.

\section{Discussion}

Analysis of the descriptive statistics showed that the majority of the participants in literature and language courses held very positive attitudes towards FL literature. These results are consistent with those of studies showing the positive impact of FL literature (Davis, Gorrell, Kline and Hsieh, 1992), as well as previous studies combining literary texts and language (Tseng, 2010). With regard to these results, we can conclude that literature facilitates FL learning, as almost $80 \%$ of the students said that the study of literature was personally rewarding and that students should be encouraged to take literature courses. Our conclusion is that students should be provided more exposure to literature courses thereby maximizing language learning.

The results regarding students' perceptions of literature instruction shed some light on what and how to teach students FL literature in EFL classes. Around 90\% pointed out that they can employ the literary activities introduced for their future English teaching. We believe that literary activities designed to enhance language learning facilitate the study of literature which most of the students feel frustrated with its unusual linguistic styles and elements such as complex characterization, plot, theme and setting.

As for the four genres presented in the literature class, most students preferred prose fiction (i.e. novels and short stories) to plays and poems. These results are consistent with those of previous studies that show that novel is perceived to be the most effective literary form while poem is regarded as the least effective literary form in helping 
them develop their literary and language skills (Akyel and Yalçın, 1990; Tseng, 2010). There is much evidence to demonstrate that most of the students view novel as the most appealing literary genre because, as Collie and Slater (1987) puts, novel can draw the students into the book and engage them in a variety of literary activities. We conclude that such results can provide useful insights into what to teach in literature class. For instance, one striking finding relates to poem which was not adequately valued by most of the students for some reason. This leads us to suggest that teachers should arrange the order of his literary presentations accordingly and explore creative ways of sparking their interest in poems.

The results yielded valuable implications for the evaluation of the classroom techniques introduced in the literature classes. The responses indicated that students in general tend to follow the practice of using class time for more student-centred approaches to responding to a text such as small group work, whole class discussion or student-led activities for exploring any aspect of the theme, plot or complex characterisation. In this context, one striking point is that there is no mention of the value of the lecture being one of the most favourable teacher activities. Our conclusion is that an array of enjoyable student-centred activities such as role play, creative writing, discussions and many other activities can be successfully integrated into the approaches mentioned above. The introduction of these kinds of activities 'is particularly important when working with students who may not as yet have developed a wish to read literature in the target language on their own initiative' (Collie and Slater, 1987: p. 8).

When students were asked to report the contribution of the literature course to the development of their language skills, students perceived most improvement in reading comprehension (93.45\%) and relatively less improvement in written expression (68.25\%) and in speaking abilities (57.75\%). Only $19.95 \%$ were satisfied with the development of their listening skill, indicating a general lack of meaningful progress in students' listening comprehension skills overall. This raises the question of the small amount of time allocated to specific listening improvement tasks in treating the literary texts. As a matter of fact, some literary activities were particularly devised in the way that will foster the use of their listening skills. For example, they were engaged in a number of activities which accompany listening skill such as 'grids, selecting and ordering tasks, jigsaw listening' thereby listening to an entire short work, or a section of a longer one (Collie and Slater, 1987; pp. 67-68). We conclude that, for students, these attempts do appear to be awarding notably in encouraging a personal response to a literary work but still remain inadequate in making considerable gains on listening skills.

As a result of the two multiple regression analysis, it was found that positive attitudes towards FL literary study were positively related to: 1) positive attitudes towards NL literature study; 2) preferred learning style; and 3) positive attitudes towards the literary activities presented for future English teaching. Self-rating of knowledge of the FL reading ability was negatively correlated to the first dependent variable. On the other hand, strong agreement that pre-service teachers should be encouraged to take literature courses aimed at integrating literary texts into ELT was positively correlated to: 1) positive attitudes toward NL literature study; 2) preferred learning style; and 3) self-rating of knowledge of the FL reading ability. Students' positive attitudes towards the literary activities presented for future English teaching were negatively correlated to the second dependent variable.

The findings that were the most consonant with previous research concerned preferred learning style. In a large scale study conducted by Davis, Gorell, Kline and Hsieh (1992), pedagogy that takes into account individual interpretations and responses to a literary text treated in EFL class, that emphasizes the content of a text, and that allows some freedom to choose selections has been found to improve student motivation. Hence, the finding regarding the impact of preferred learning style on attitudes towards literature is encouraging because it suggests that literature instruction may promote students' motivation to build upon their language and literary skills. Likewise, the positive relationship between NL literature appreciation and FL literature appreciation is of particular interest. This result implies that studying literary texts selected from Turkish literature can also assist students in fostering reading habits as well as literary skills when engaging in FL literature. Therefore, we conclude that both FL literature study and NL literature study should be paid due attention in the course of literature study because they have much in common regarding the literacy skills. Overall, the findings in relation to both preferred learning style and NL literature study also apply to another dependent variable indicating that pre-service teachers should be encouraged to take literature courses in the Department. As the literature presentations and the results of the study display, literature courses prove useful provided that they are incorporated into NL literature study and a variety of classroom activities involving the application of students' preferred learning styles.

Another significant correlation was found between students' positive attitudes toward literature activities and literature appreciation. This result suggests that students find literature study rewarding and that they feel comfortable with the literary activities introduced as they practically provide room for their future English teaching. Thus, literature teaching becomes meaningful and purposeful, throwing some light on the issues surrounding teacher 
education.

The last expected finding was the significant relationship between self-rated FL reading ability and positive attitudes toward taking literature courses in the Department. This relationship seems to indicate that those students who value reading ability highly may perceive that their needs for improved reading skills are being met in literature classes.

\section{Conclusions}

The results of this study yield some pedagogical implications in terms of what to teach and how to teach literature in EFL language classes. We feel that two aspects of these results are of particular interest. The first is how they parallel current thinking about students' reading habits and preferred learning strategies. The link between these widely-held beliefs and our findings underscores the need for continuing investigation of students' reading habits in literature class. In such a language class where classroom activities are primarily student-centred, it is possible, for example, to introduce novels or short stories in the first instance because they are cited as easily arousing students' interest in the sense of what literature to teach in EFL classes. On the other hand, we believe that plays or poems can be introduced later, capitalizing on some well-designed activities which would spur their attention to these literary genres.

The latter is the likelihood that modifications in instructional practices suiting students' perceived literary and language needs will have a positive effect upon students' attitudes towards studying literature. In this context, this study has attempted to explore one possibility of how the teaching of literature can be made more accessible to EFL students, incorporating students' attitudes along with the accompanying components of teacher's own goals and selection of literary texts. We believe that, if taken up, such a strategy for the teaching of literature which incorporates students' literature preferences into teachers' instructional practices specially devised for the particular groups of students will improve both the literary and language competence of students.

\section{References}

Akyel, A., \& Yalçın, E. (1990). Literature in the EFL class: A study of goal-achievement incongruence. ELT Journal, 44(3), 174-180. http://dx.doi.org/10.1093/elt/44.3.174

Banegas, D. (2010). The role of literature in ELT - Part one. [Online] Available: http://www.teachingenglish.org.uk (September 14, 2010)

Brumfit, C. J. (1981). Reading skills and the study of literature in a foreign language. System, 9(3), 243-248

Carter, R. (1988). Directions in the teaching and study of English stylistics. In M. Short (ed.), Reading, analysing and teaching literature. Harlow: Longman.

Carter, R., \& Long, M. N. (1991). Teaching literature. New York: Longman.

Carlisle, A. (2000). Reading logs: An application of reader-response theory in ELT. ELT Journal, 54(1), 12-19. http://dx.doi.org/10.1093/elt/54.1.12

Cook, G. (1994). Discourse and literature. Oxford: Oxford University Press.

Collie, J., \& Slater, S. (1987). Literature in the language classroom: A resource book of ideas and activities. Cambridge: Cambridge University Press.

Davis, J. N., Gorell, L. C., Kline, R. R., \& Hsieh, G. (1992). Readers and foreign languages: A survey of Undergraduate attitudes toward the study of literature. The Modern Language Journal, 76(3), 320-332

Duff, A., \& Maley, A. (1990). Literature. Oxford: Oxford University Press.

Elliott, R. (1990). Encouraging reader-response to literature in ESL situations. ELT Journal, 44(3), 191-198. http://dx.doi.org/10.1093/elt/44.3.191

Hirvela, A. (1996). Reader-response theory and ELT. ELT Journal, 50(2), 127-134. http://dx.doi.org/10.1093/elt/50.2.127

Hirvela, A., \& Boyle, J. (1988). Literature courses and student attitudes. ELT Journal, 42(3), 179-184. http://dx.doi.org/10.1093/elt/42.3.179

Hall, G. (2005). Literature in language education. New York: Palgrave.

Lazar, G. (1993). Literature and language teaching: A guide for teachers and trainers. Cambridge: Cambridge University Press.

Mckay, S. (1982). Literature in the ESL classroom. TESOL Quarterly, 16(4), 529-536

Oster, J. (1989). Seeing with different eyes: another view of literature in the ESL class. TESOL Quarterly, 23, 
85-103

Parkinson, B., \& Thomas, H. R. (2000). Teaching literature in a second language. Edinburgh: Edinburgh University Press.

Short, M. (1996). Exploring the language of poems, plays and prose. Harlow: Longman.

Smith, M. S. (1972). Some thoughts on the place of literature in a practical English syllabus. ELT Journal, XXVI, 274-278. http://dx.doi.org/10.1093/elt/26.3.274

Spack, R. (1985). Literature, reading, writing, and ESL: Bridging the gaps. TESOL Quarterly, 19(4), 703-725

Tseng, F. (2010). Introducing literature to an EFL classroom: Teacher's presentations and students' perceptions. Journal of Language Teaching and Research, 1(1), 53-65

Tucker, H. (2006). Communicative collaboration: Language, literature, and communicative competence redefined. The Modern Language Journal, 90(2), 264-266

Widdowson, H. (1984). Explorations in Applied Linguistics, 2. Oxford: Oxford University Press.

Table 1. Undergraduate Attitudes toward the Study of Foreign Language Literature

\begin{tabular}{lccc} 
Items & F & M & SD \\
\hline Finds Study of Literature in FL Personally Rewarding & & & \\
Strongly Agree & & 1.971 & .965 \\
2 & 39 & 37.1 & \\
3 & 40 & 38.1 & \\
4 & 17 & 16.2 & \\
Strongly disagree & 8 & 7.6 & \\
\hline Feels Majors Should Be Encouraged to Take Literature Course in the FL Department & \\
& & 1.971 & 1.042 \\
Strongly Agree & 42 & 40.0 & \\
2 & 37 & 35.2 & \\
3 & 16 & 15.2 & \\
4 & 7 & 6.7 & \\
Strongly disagree & 3 & 2.9 & \\
\hline
\end{tabular}


Table 2. Undergraduate Attitudes towards Literature Instruction

\begin{tabular}{|c|c|c|c|c|}
\hline Items & $\mathrm{F}$ & $\%$ & M & $\mathrm{SD}$ \\
\hline \multicolumn{5}{|c|}{ I can use the literary activities introduced for my future English teaching } \\
\hline & & & 1.771 & ,992 \\
\hline Strongly Agree & 51 & 48.6 & & \\
\hline 2 & 38 & 36.2 & & \\
\hline 3 & 9 & 8.6 & & \\
\hline 4 & 3 & 2.9 & & \\
\hline Strongly disagree & 4 & 3.8 & & \\
\hline I like to read novels & & & 1.742 & 920 \\
\hline Strongly Agree & 54 & 51.4 & & \\
\hline 2 & 30 & 28.6 & & \\
\hline 3 & 16 & 15.2 & & \\
\hline 4 & 4 & 3.8 & & \\
\hline Strongly disagree & 5 & 1.0 & & \\
\hline I like to read short stories & & & 1.609 &, 849 \\
\hline Strongly Agree & 60 & 57.1 & & \\
\hline 2 & 31 & 29.5 & & \\
\hline 3 & 10 & 9.5 & & \\
\hline 4 & 3 & 2.9 & & \\
\hline Strongly disagree & 1 & 1.0 & & \\
\hline I like to read plays & & & 2.409 & 1.245 \\
\hline Strongly Agree & 32 & 30.5 & & \\
\hline 2 & 27 & 25.7 & & \\
\hline 3 & 24 & 22.9 & & \\
\hline 4 & 15 & 14.3 & & \\
\hline Strongly disagree & 7 & 6.7 & & \\
\hline I like to read poems & & & 2.238 & 1.282 \\
\hline Strongly Agree & 42 & 40.0 & & \\
\hline 2 & 24 & 22.9 & & \\
\hline 3 & 17 & 16.2 & & \\
\hline 4 & 16 & 15.2 & & \\
\hline Strongly disagree & 6 & 5.7 & & \\
\hline
\end{tabular}

Table 3. Language Skills Gained through Studying Literature

\begin{tabular}{lll}
\hline Language skills & F & $\%$ \\
\hline Speaking & 55 & 57.75 \\
Listening & 19 & 19.95 \\
Writing & 65 & 68.25 \\
Reading & 89 & 93.45 \\
\hline
\end{tabular}

Table 4. Multiple Regression: Attitude toward Studying Literature in the Foreign Language Model Summary

\begin{tabular}{lllll}
\hline Model & $\mathrm{R}$ & R Square & $\begin{array}{l}\text { Adjusted } \\
\text { R Square }\end{array}$ & $\begin{array}{l}\text { Std. Error of } \\
\text { the Estimate }\end{array}$ \\
\hline 1 & $.831 \mathrm{a}$ & .691 & .613 & .6005 \\
\hline
\end{tabular}

a. Predictors: (Constant), Finding Literature in NL Rewarding, Preferred Learning Style (6 Items), Using the Literary Activities for Future Teaching, Self-Rating of FL Reading Ability 
Anova ${ }^{b}$

\begin{tabular}{llrlll}
\hline Model & Sum of & & & & \\
& Squares & Df & Mean Square & F & Sig. \\
\hline 1 Regression & 66.980 & 21 & 3.120 & 8.844 & $.000 \mathrm{a}$ \\
Residual & 29.934 & 83 & .361 & & \\
Total & 96.914 & 104 & & & \\
\hline
\end{tabular}

a. Predictors: (Constant), Finding Literature in NL Rewarding, Preferred Learning Style (6 Items), Using the Literary Activities for Future Teaching, Self-Rating of FL Reading Ability

b. Dependent Variable: Finding Studying Literature in English Personally Rewarding

Coefficients $^{\text {a }}$

\begin{tabular}{|c|c|c|c|}
\hline Model & Coefficient (SE) & Standard. B. & P-Value \\
\hline 1 (Constant) & $(.365)$ & & .632 \\
\hline Finding Literature in NL Rewarding & $(.084)$ & .526 & $.000 *$ \\
\hline Preferred Learning Style (6 Items), & $(.106)$ & .629 & $.000 *$ \\
\hline Using the Literary Activities for Future Teaching & $(.087)$ & .213 & $.014 *$ \\
\hline $\mathrm{L}$ & 7.064E-03 (.119) & .632 & .953 \\
\hline
\end{tabular}

a. Dependent Variable: Finding Studying Literature in English Personally Rewarding

Appendix A: LITERARY WORKS PRESENTED

Novels

1. Lord of Flies

2. Animal Farm

Short Stories

1. Hitchhiker

2. The Edge

3. The Star

4. The Spread of Ian Nichol

5. The Open Window

6. Sredni Vashtar

Poems

1. The King of China's Daughter

2. My Papa's Waltz

3. Telephone Conversation

4. The Couple Upstairs

5. To Women, as far as I'm Concerned

6 . You and I

Plays

1. Romeo and Juliet

2. The Sandbox

3. Look Back in Anger

4. King Lear

5. Macbeth
Sources

www.sparknotes.com

www.sparknotes.com

Dahl, R. (1979)

Narayan, R.K. (1984)

Gray, A. (1984)

Gray, A. (1984)

Saki (1982)

Saki (1982)

Roberts, M. (1965)

Roberts, M. (1965)

Swan, M. (1979)

Morrison, B. And A. Motion (1982)

Lawrence, D. (1950)

McGough, R. (1982)

www.sparknotes.com

www.jiffynotes.com

www.sparknotes.com

www. pinkmonkey.com

www. jiffynotes.com 


\section{Appendix B: LITERATURE QUESTIONNAIRE}

\section{Literature Questionnaire}

The purpose of this questionnaire is to contribute to improving the instruction of literature in an EFL classroom. The aim is NOT to evaluate instructional professors and teaching assistants. All answers will be anonymous. Thank you for taking the time to answer the questions thoughtfully.

Place a check $(\sqrt{ })$ after the number or word that most closely agrees with your opinion.

1. I find studying literature in my own language personally rewarding.

$1 \_2 \_3 \_$___ 5

Strongly agree

Strongly disagree

2. I find studying literature in English personally rewarding.

1

Strongly agree 5

3. Pre-service teachers in the Department of English should be encouraged to take literature course.

$1 \_3 \quad 3 \quad 4 \quad 5$

Strongly agree Strongly disagree

4. I enjoy reading literature in my own language, if I will be expressing my personal opinion about it.

$1 \_2 \_3 \_4$

Strongly agree Strongly disagree

5. I enjoy reading literature in English, if I will be expressing my personal opinion about it.

$1 \_2 \_3 \_4$

Strongly agree Strongly disagree

6. I enjoy reading literature in my own language, if I will be looking for underlying meaning.

$1 \_2 \quad 3 \quad 4 \quad 5$

Strongly agree

Strongly disagree

7. I enjoy reading literature in English, if I will be looking for underlying meaning.

1 2 3 4 5

Strongly agree Strongly disagree

8. I read unassigned Turkish Literature for pleasure.

$1 \_2$ _ 3 _ 4 _ 5

OFTEN

NEVER

9. I read any types of literary text in English for pleasure.

$1 \_2 \_3 \_$__ 5

\section{OFTEN \\ NEVER}

10. I enjoy reading literature about people and experiences similar to my own.

1 2 3 4 5

Strongly agree Strongly disagree

11. I enjoy reading literature about people and experiences unlike my own.

1 2 3 4 5

Strongly agree Strongly disagree

12. I can use the literary activities introduced in this course for my future English teaching. 1 2 3 4 5

Strongly agree Strongly disagree

13. How valuable have you found these approaches to teaching literature? 
a) Small Group Work

${ }_{\text {EXTREMELY USEFUL }}^{2}{ }^{3}-5-5$

b) Lecture (Extended talking by the professor with occasional student questions)

$1 \_3 \_3 \_5$

EXTREMELY USEFUL NOT USEFUL AT ALL

c) Whole-Class Discussion (Teacher-student talking, with little or no student-student interaction)

${ }_{\text {EXTREMELY USEFUL }}^{2}{ }^{3}-5-5$

d) Student-Led (Students do oral reports, followed by discussion-seminar format)

${ }_{\text {EXTREMELY USEFUL }}^{2}{ }^{3}{ }^{4}-5-$ NOT USEFUL AT ALL

14. I like to read literary works.

$\begin{array}{lllll}1 & 2 & 3 & 4 & 5\end{array}$

Strongly agree

Strongly disagree

15. I like to read novels.

$1 \_2 \_3 \_$__ 5

Strongly agree

Strongly disagree

16. I like to read short stories.

$1{ }^{2}-3 \quad 3 \quad 4 \quad 5$

Strongly agree

Strongly disagree

17. I like to read plays.

$1 \_2 \_3 \_4 \quad 5$

Strongly agree

Strongly disagree

18. I like to read poems.

$1 \_2 \_3 \_4 \_5$

Strongly agree

Strongly disagree

19. I like to be introduced to more literary works.

1

$$
2
$$
3 4 5

Strongly agree

Strongly disagree

Rate your knowledge of English.

20. My knowledge of English Grammar is

$1 \_2 \_3 \_5$

EXCELLENT 5

My ability to write papers in English is

$1 \_2 \_3 \_4$

EXCELLENT

POOR

22. My ability to read in English is

$1 \_2 \_3 \_4+5$

EXCELLENT

POOR

23. My vocabulary knowledge in English is

$1 \_2+3 \_4 \quad 5$


EXCELLENT

24. My ability to speak English is

1

EXCELLENT

4

My listening comprehension in English is

1 2 3 4

EXCELLENT 5

My knowledge of the culture of the countries where English is spoken is EXCELLENT 4 5

27. What language skill(s) does studying literature help improve specifically?
a) Speaking
b) Listening
c) Writing
d) Reading 